さ全でしはの、を統は国

叔国あと群工ばし市的林鉄国

そケこせ場なして地すをを

のミといといこい場るは新 一

生力吕しょ。のる産煙さ長

産儿わ、京こ生可業笑凡思

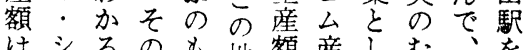

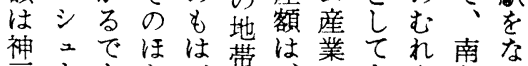

戸!市とはに、のさを北か

のズろんが加望へに

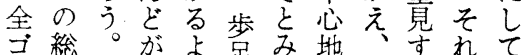

厶生そケう走に帯いるぞ、

生産しミな京をでまでれ東

産量て力多みそあをあ五は

額のこル数いれる年ろ○兵

のじの

五に数二細るら五明１加

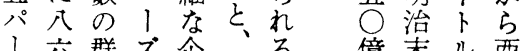

七六群芣企熛煙意条ル西

ン1工製が突突にい地鹰

上場造、杢工方带取

をンの・告場加い駅

しトな加このだい神、に

めがか工ろ周汁生户人い

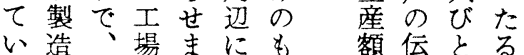

†よがケ業多税工署て磨ち、年、

地

場

産

業

ケ

ミ

力

ル

構

造

z

肴 地

業域

忠性

バそ力底た署索势い兵九神

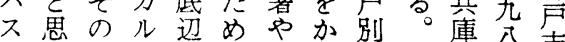

. わ関・の、労ぞ訪し禹八市

シれ連 シ 状工動え問加区1業

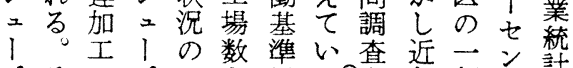

ズそIズーさ局る2る 年部卜註

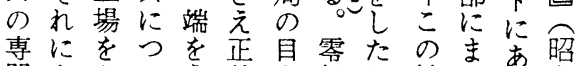

門よふいう確を細と地たた和

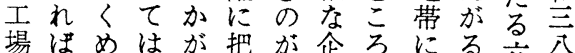

を、たい握れ業で火る六年

の第桨西しでて范は災の元

そ1洗神るき社多、范地工で

い表を邑こな会くそあ带場は、

ての推労之いのてのいに市

ほう定働がと襄浮管引集市

とにる基きうにがだ隼きさ長の

ん若の局る事沈は沙長て思ゴ

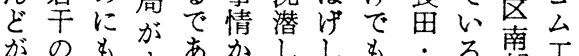

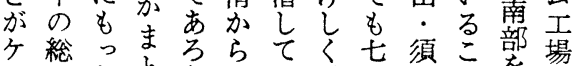

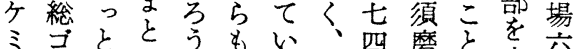
カ

ル靴都たとこ文の市禹し心分 
第 1 表 神戸市のゴム履物製造・加工（規模別）工場数（明和36年）

\begin{tabular}{|c|c|c|c|c|c|c|c|c|}
\hline 業规㮔 & 5 人未満 & $5 \sim 10$ 人 & $1 \sim 12$ 人 & $\sim 50$ 人 & $\sim 100$ 人 & 101 & $\sim 1,000$ & 合 計 \\
\hline ゴム履物製造 & 18 & 64 & 165 & 59 & 33 & 34 & 1 & 374 \\
\hline 貸 I 場 & 3 & 13 & 25 & & & & & 41 \\
\hline 底焼 ス ポンジ & 7 & 25 & 26 & 4 & 1 & 1 & 1 & 65 \\
\hline ビニール糊引 & 6 & 17 & 10 & 1 & & & & 34 \\
\hline その他(甲被加工等) & 62 & 45 & 16 & 1 & & & & 124 \\
\hline & 96 & 164 & 242 & 65 & 34 & 35 & 2 & 638 \\
\hline & 15.0 & 25.7 & 37.9 & 10.2 & 5.3 & 5.5 & 0.3 & 100. \\
\hline
\end{tabular}

（西神戸労働基準局資料加ら引用）

收報戸 $\stackrel{2}{2}$ 報 乩 告市神告亯 畫ゴ神畫 ゴ神 昭王市明王市 和業経 和業 経 四実済兰総済 態局六合局 年調司年。祅神
あ率虑もがるパ零り 方のち場場三つき

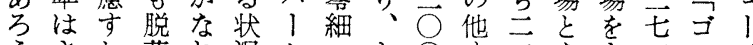

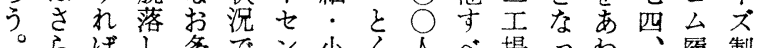
らばし多でン小く人べ場っわ、履製 に、てくあ卜さに以てをてせそ物造 上現いこるを場至忑がのいるの近

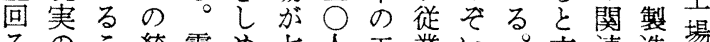
るのこ統零め七人工業い。六連造て

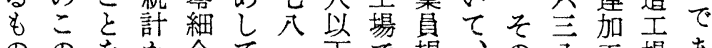
ののを古企て、婴で規、の公場あ で比考ら業い六のあ模そう工工はる
時細ここ集零のそ機みを方械借 つ業れれ地企之主のた象の産統 よは、に問業あ体なしとく会的 い、そた壓がわを加てすみのな 支親のいが、せなでいるあ発地

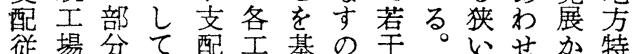

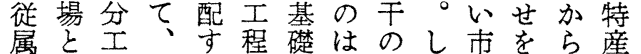
関生程大る堡職簡た場基々産

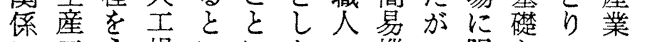
に工う場いにた機っ限々のの よ程けのう社家副械て定しこば つももの会内業がそさてさあ

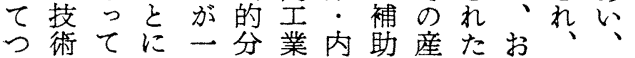

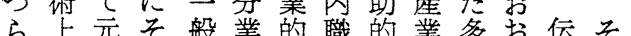
ぬで下の形をなな役構種む統の 加請生態構いそ割造少ね的長 れ補文産で成しの壱は量地ない て完又王あし、伝はき生方手時 関下程 い係請 の る。纱分 たつ業

そちなの

のながな 技がるか 術ら中に 水、小く 準同零
る、二統たわ産市工代 そェ的しめに場業的 れ入技ててそや的変 らっ術い停の特技せ をクとる滞存殊術ん 産于安に的続なとの 地二価しでの消安過 問 $>$ 労七、基費価程 屋的㗢も生礎需労で 户な另産を要働機

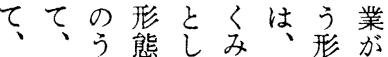
さそえ態息伝態密加 しのにと系め統は集し ず生展る列ら的、况 め産開こ化れなか、う 三機さとさる在なそし 構れがれ。来方れて のをる少たま産ずら一 パ中伝な中た業しの定 夕心統く小特がもつの lに的な零定地例よ地 ンない細の方のい域 をそ地。工大特少互的 構れ方々場工産な存基 成 ら特しが場産い性盤 寸諸産て群の業こにの

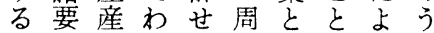
こ素業れい辺しでっえ そが方方にてはてに 加打㞦る、存な二 でり工は注そ続い産同 きな場、あのし。業、 るす场一心下て\&芯業 産請定に請いっ構種 業静のも工ると成の 構を地、場淮をさ中 造基域こやあ典れ小 に礎的う外い型る零 つ と基し業に的と細 いし盤た部多にい企 


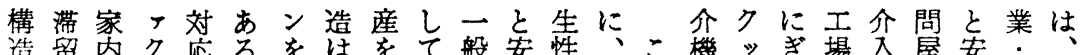

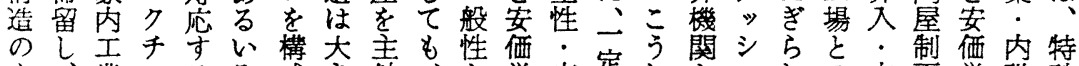

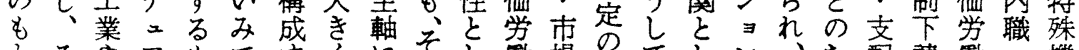

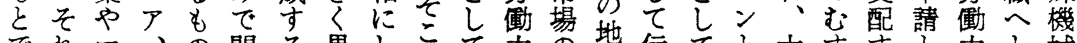

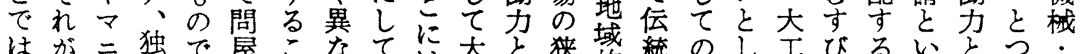

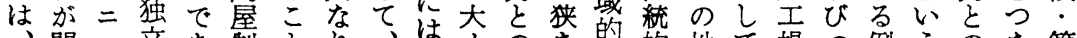
問二辛市制飞り、問力のあ的地て場つ例うのな簡

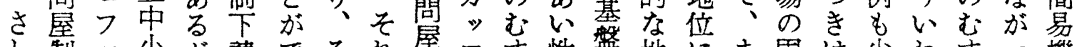

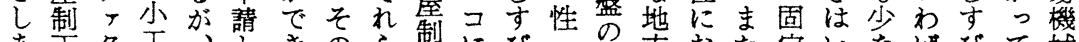
あ下クエ、をきのら㹕にびう方おた定いなはひて械

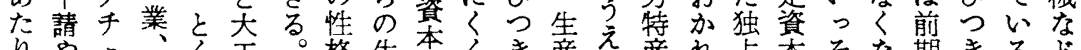

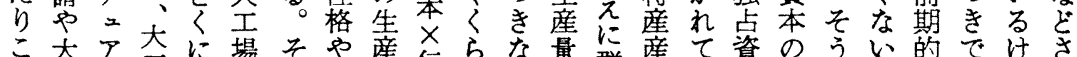

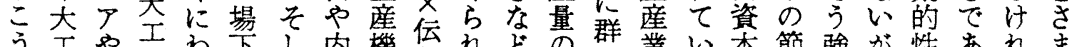

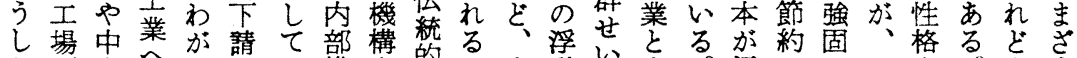

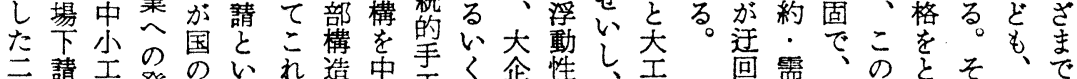

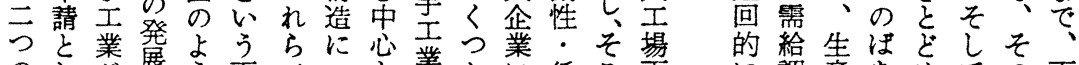

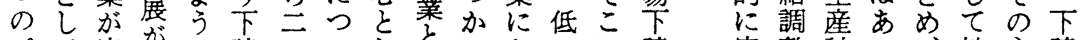
パて安直に請ういしとのたいに請安整計いい地主請 夕再価喤、制のてた独共心技はの価卢画は問方体系 1 編労線家度㕣別諸点通す術零中学景の生屋特を列 ン成㗢的芮の夕個要餈性る水細小㗢気寸産餈産なの

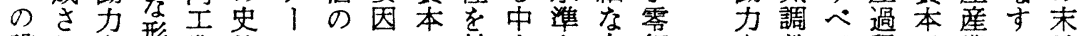
設れを艮業的シ三のメ抽小な自細を整て程が業の端 定て支態展のうお簡象零ぞ企利のをに生のはは

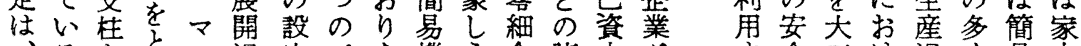

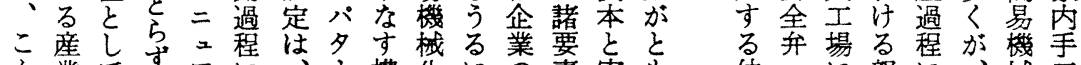

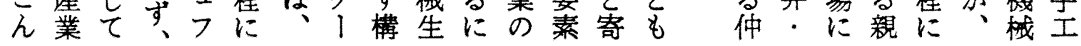

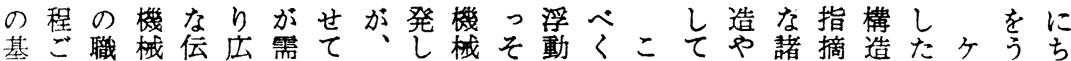

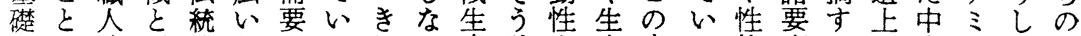
のに的低的大量るわ心産助を産る産る格素るで小力な中 う異技貿技衆にのめこと長もさ業よにのこも零儿っ小 えな術。術消大とてと企しっれはううく飞、細・て零 にり出安を費き比限注業、てる最にいみ分こ企シは細 、、こ価必のな較定いの高い多終思てあでれ業こい企 小それ労要市限守さう拡いる種消わ前わきる はな業 規こに㗢飞場界れれま大投。省費れ省さる三しスいの 模にく少守ををたでを機さ量財る者り。うて産で な貿わにるも課、特もき性方生と。の方しのの業あ部

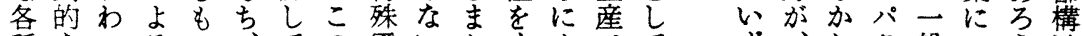
種なっるの、ての需、たくめでてず、多航うう造

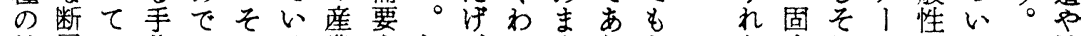

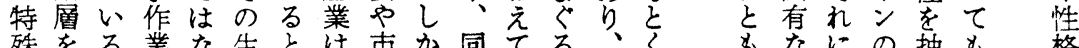
殊をる業な生と注市加同てる、くをなの抽を格 加加加のい産は素場し時いしまに異制もを象、の Iたく过い材の反にるいた各な度かれ专こ分

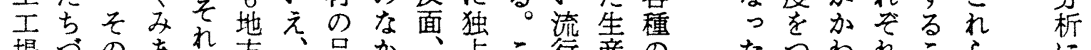
場うのあれ方品汃占こ行産のたうわれこらに

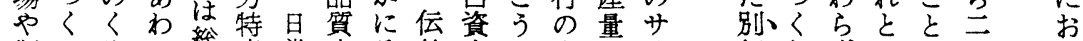

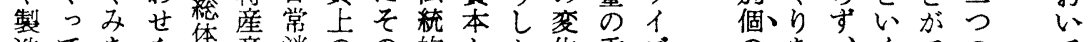
造てあを体産消のの的かた花季市のあ、くでのて

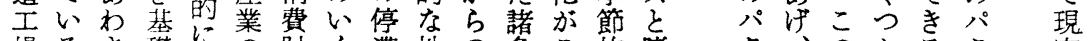

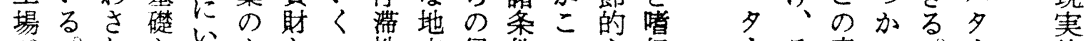

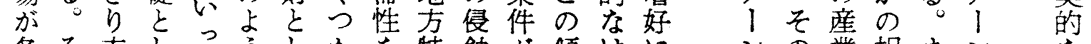

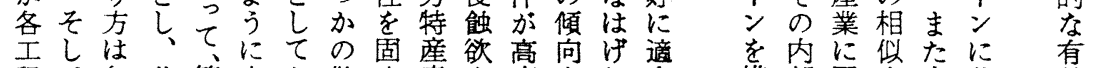
程て各若簡高加難定産も度をし合構部固点内共效 ごこ工手易度な点さ業誘ないい导成構有を部通性 
そつ高種え地広が従れやで関のか特工こ生な製てと

しのい少る方いこれ属ず独あ係工で有業ろ産地品うに

てパ依量。特大のての、卢るの場零な者名過方がめ分 こ夕存生し産衆よい関ま資。なで細々にら程特完な化 う1性産加産消うる係た本そかおな貸作、に産成が。

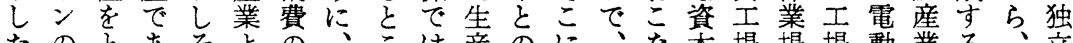
たのとあそよの境場動業る、立 諸まほるれら市ヶろな過固ははうに留を建式としそし 要さめとがも場ミにく程定地け少よ制質物機相くれて 素にていはむを力も济に方し数るが貸と械似みら存 の中いうぼしもルこむおた特いの独うしコがしにの在 固間る大しろ方。のし活つ産過二音み、公導たな生し

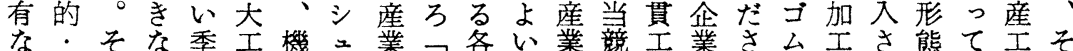

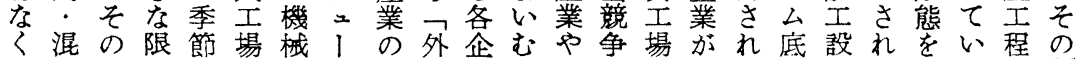
み合意界的の加ズ構注業す大とと乱て。備、しるの間 あ的味は浮下工産造間び工浮な立い加の一め。つげ わなで、動請を業的とのつ場沈らしる硫み定しそなき

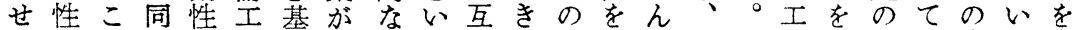
を格の時々場礎特う存や下々で全そ程哲工心構互内 基を産に高にと日徽ヨ性々請り、製しを有場る造存職 礎も業手いちす常がコはの工ひ履造て貢し設がは関や とっの工投かる消指の二支場ろ物工こ加て備、図係

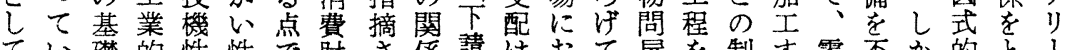
てい礎的性性で財さ係請はおて屋を制す零不加的々!

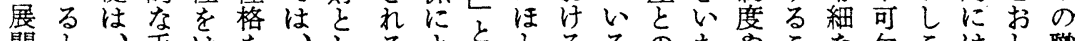

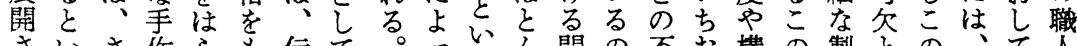

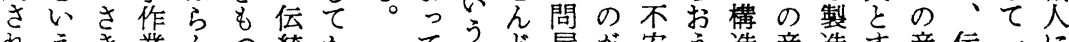

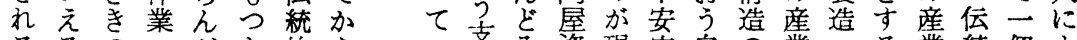
るるのへた齐み資現定自の業・る業統個よ 制。三多いなり配方本状な身なに加との的のっ

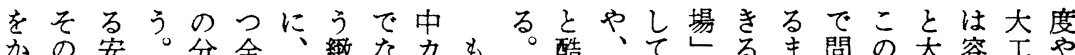

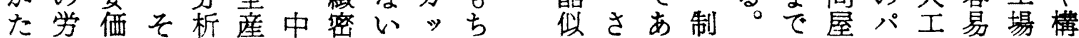

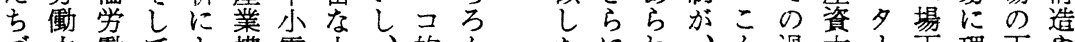

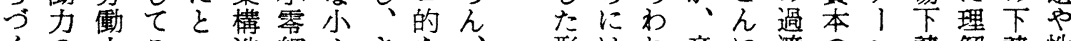
くの力こっ造細力さな、 っ問のんての企ッらく中

て題質にこ底業コにく小 小を队方边出的細り零

る媒構のしにそなか方細

こ介成中た再のくい注企

之注尔編停々分業 もし、零夕成滞り析まに

少てこ細、さ的方のたつ

な、う企ンれ性もた問い

く特し業のて格可め題て

な定たを設いを能に提の いのパ、定るとでは起こ

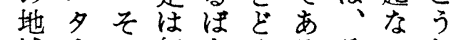
域 「の無あめろそいし 的ン根意心なう狄した 基衣底味、架。そ仮至 盤相にとそらしれ説つ と関おはの重かに的の 固をいい内畳しつなパ 有なてえ部的わ心域夕 のし、な構にがてを方り 堆のでシ なさえでや積のいるに がらてあ性しよっもよ

りにいろ格ううそのる

形はれ産に渡のン請解請性 態イた業ち期支はとさ工格 妾琞革でに配、心れ場が

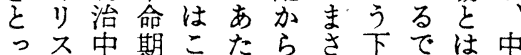
ての期にのるはに請あ異小 いコにお産独な手制ろな零 るヴおけ業立れ工度うつ細 のエ汁るに中、業の。た企 もンる機固小まか史さつ業 あ卜愛械有工たら的き第々 なり知制な業独本展の至し が市県工もの占格開二こて ちの罢場の確資的過つのは 偶絹の経と立本な程のパ 然織ガ営考期の機にパ夕伝 之物 ラに考に下械対夕１統 は業紡心元效生応1ン的 いののたら店と産さンにな

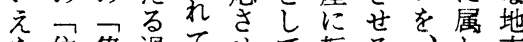
な住集過てせて転る、、方 心舎合渡いる再換々問て特 も工工的るこ編す寸屋 の場場形子と成るれ制る産 が思態貸がさ過は下こ業 あ制制と工でれ程、請とや 
連ルわはつが労条て 業大あもみ産いン定て業はと

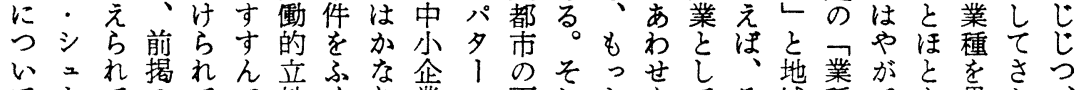
でてのてで地くり業ン下しとをてそ域種てん異か

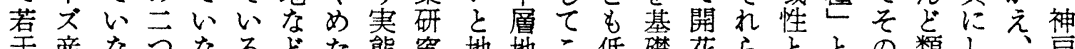
干産なつなるど態究地地こ低礎花らととの類しれ戸 の業いのいのを原調の域帯の幦としはの地舞似なつに 考を。簡。にと料査な性にむ・しい固域台しがゔは

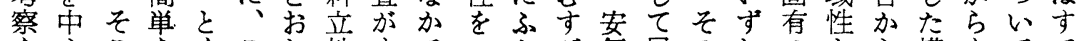
を心こなくこし地すでつかひ洒展のれのと構もてで こにアで統にうて・寺もなくつな開零もつの姿造、総に こ本計コし、伝み、ぐはき家さ細本なむををいず明 ろ神稿報公た地統、地ひいを計れな格㔔す活もず㕕治 み户で告や産域的そ方とり媒補る資的りびしつれ靴中 よのは書ケ業的技の特うこ狳助産龺なをつててもと期

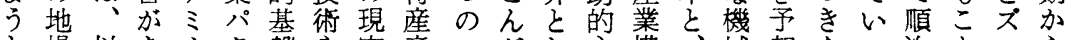
と場以あカ夕盤や実産つたし主構、械想をっ次んッら 思産上るル、の関の業よのて婦造簡生さこたこにクマ う業のだ・ンむ連構やいで、労は易産せ总のの方靴ッ

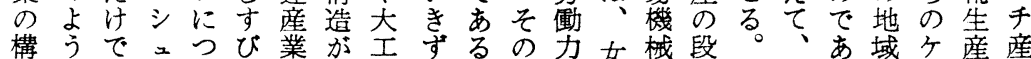
造な、いつのあ場な。豊と李と階結一るのミ方業

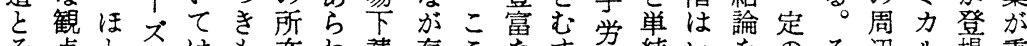
そ点々産はを在わ請存こ焉す働純いをのそ边ル場重 のかん産ほ、ににの在に供ひ働なるされれに・し要

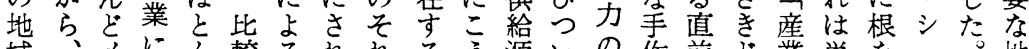

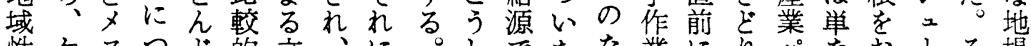
性ケスつぞ的立、に。しでたな業にりパなおそ場 のミがい手分地自つたあの加の地し夕るろ多れ産 関力くてが析・然い産るででく場て1特し䇭ら業

しれり機る力なる

てに方械たない各上 の茯は加め 工寺程々基諸乃程よ 程るこ手本要う地 う に作々作的妻。がな そ業に業なをそ、観 っ内少の単相れも点 て容なく位互はっか 企的みを関なとら 業労のあ構連にも産 加㗢質わ成的よ基業 独力的せ守にり本構 立の断をるむも的造

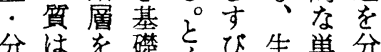
化大しににつ産位析 しきめしにけ設立卞 そ異多念そ備しる こな各ら力れ技考あ

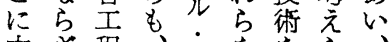
内さ程、浮なら 包るのそン統いれ生 さ技の产しな産

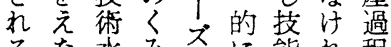
るな水み産に能れ程

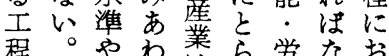
程。やわ羓ら学なお

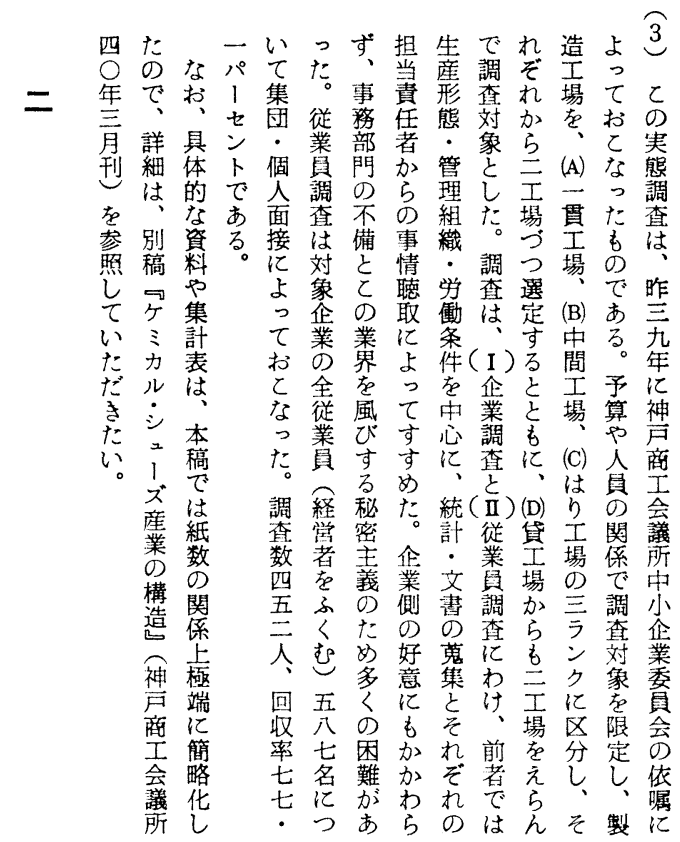


第 1 図ケミカル・シューズ生産工程

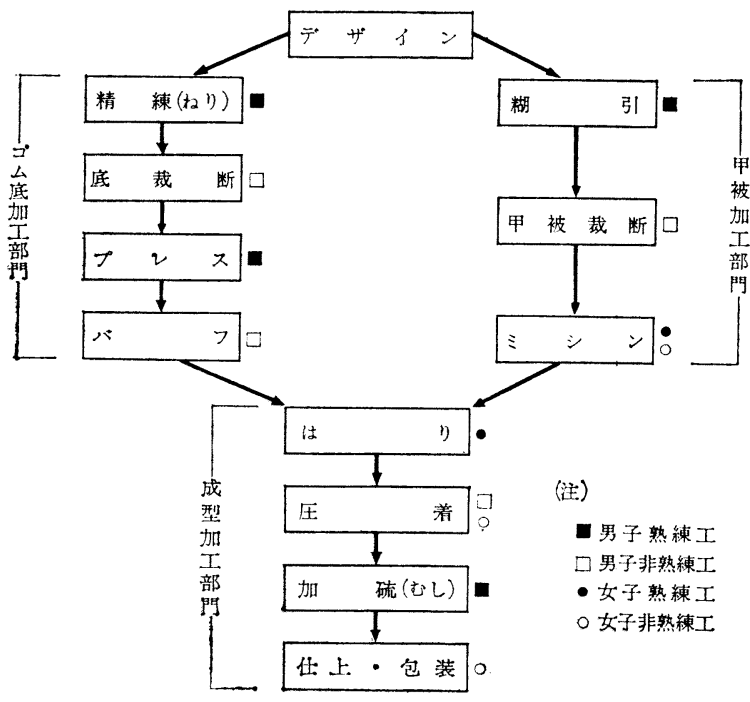

がをそととちが

で中 し相に企

き心てて関企業

ると各、的業規

でし種各にの模

あた企企体性の

ろ構業業系格格

う造間の化や差

そ関部れ部艻

の連構る構た

地を造。成ち

域さをつをう

性ぐあま規く

とるきり定っ

の $こ こ し て$

加衣加こ、い

かににで管る

わよしは理現

りっな、組 状

方てが工織の

を、ら程や

まこす、職労㗢を

ら産ら種条は

か業にを、件

にの生基もそ

す生産本それ

る産工的のが

こ機程単基た

なて㗢っ男っ人大しをきこ置りシ革なお各れりの部

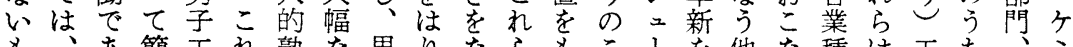

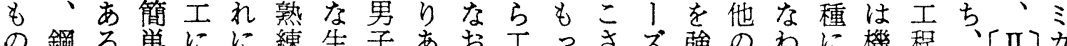
の鋼る。単にに練生子あお王っさ无強のわに機程门[II]力 は鉄。なよたで地熟わつ程てれの行コれ共械・も討儿 へ製と簡るいあを練せよにいいている通のプっ被・ ニのく易機しるシエるくもなとれた産して様レと加シ ヤぬに機械ゴワに糊と少いくはの業した式スも无ュ

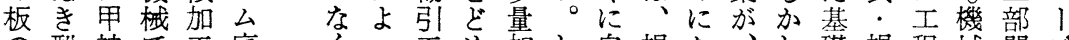
の型被で工底くっ王め加し自規た、し礎規程械門

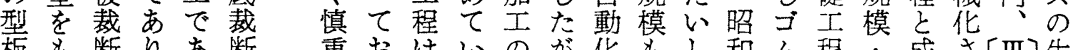

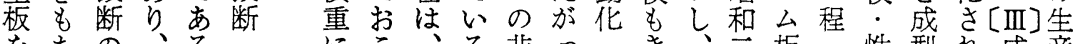
をちの、る・にこ、る非っ・き、板・性型れ成産 あいほほ隹甲はな電の能て標わ零五: 基能加て型王 てたあと、被りわ動で率こ隻め細年へ幹の志い加程

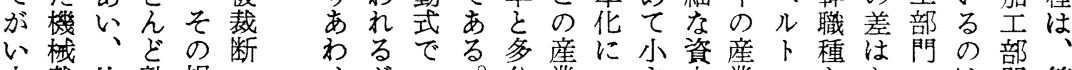

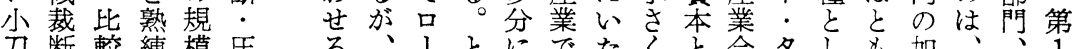

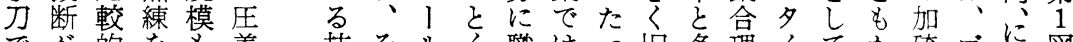
でが的をも着技そルく職は监多理イてか硫コに図

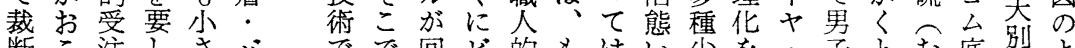

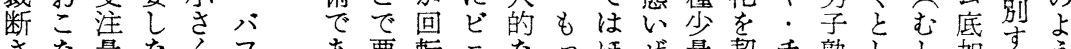
さな量なくフ要転二なっほぜ量契手熟しし贺るす

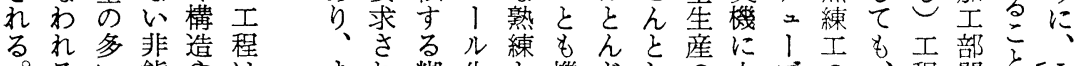
こが品能操は れ、種な作 W に量に単もず はのつ純いれ か少い労たも

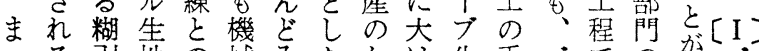
っる引地の械みたケは生手コでの乫ざ た熟機とむ化る水三は産に公あ精で公

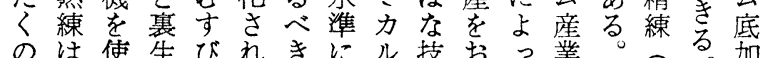

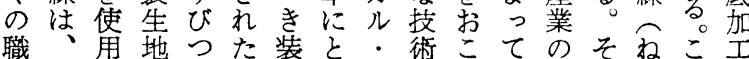


う浮て出いお的熟作い甲

こ動さ莱るお職練業わ被かシあ程合むてこるをれわり

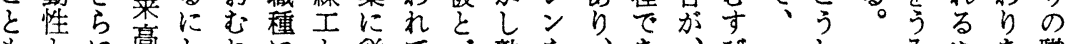

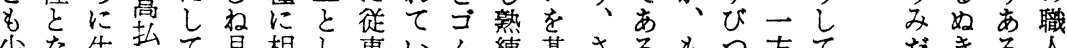

少な生払て月相し事い公練基さるもつ方てだる人

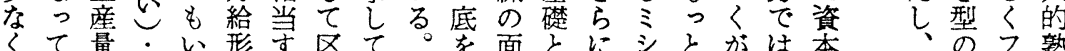

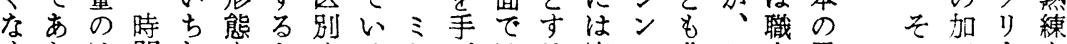

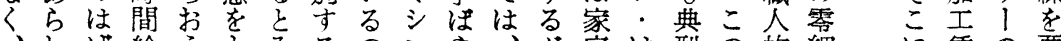

わげ給うとみるの方や、が庭は型の的紐に覒の要

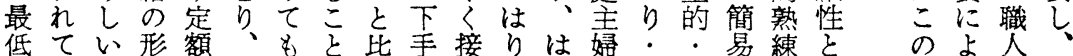

生い浮態のそよ方較間着エりの仕集機に多産るで手

活る動と収のいで等やしが.内卡械さ種業コあ裁

の。性非入貨できれ仕ても仕職の的とさ少のるる師

安閑が常が金あるぼ上ゆっ上で各に低光量多卜。の

定散し傭保水乃方、工〈と王あ工し筫ら生種高二多

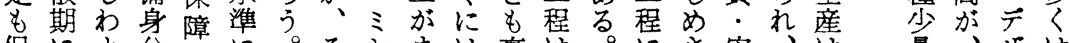

保によ分さに。そシまは高は。にさ安、はは量、サは

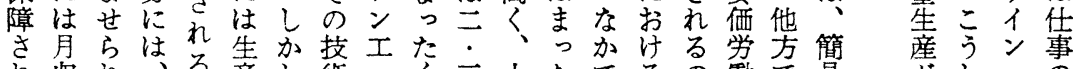

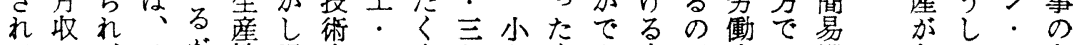

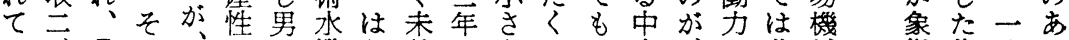

い:月の、の子準り熟のなのミ高、に非械街作サる

な三別低女低工は土な経品手年こよ能の 的業イこ

い○収水子さの男は補験!作ン命のる率導に形てと

こ○人準エがぼ相助をル業エの産単な入態こに

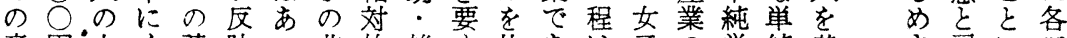

産円”大く請映い非的雑香片あは子の労純基さ雇に工

業ときわ取しは熟に役る手る動労主㗢労礎勈了場

のいなえ給て、練は的とに。力㗢要の㗢にて関くを

家のの1一ち展はす二をそがエを場業れ場ててをな基

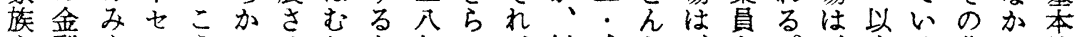
や型をンういせしと年にが以成ど、も故曹に的 親へおくとてろいこ朝昭前型は資 $○$ - (A) のの富集な

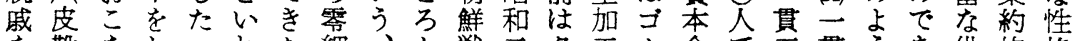
を靴なし二わた細、加戦三多工金て工貫うあ供的格 中製うめ貫ねもないら争吾イの底金い場志なる。給には

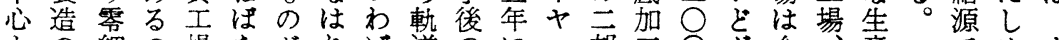

との細の場ながりは道のに: 部只○方全鏟でめま

し木なは・方多工没にコはチ膶部方こ生(B) 疘あささ

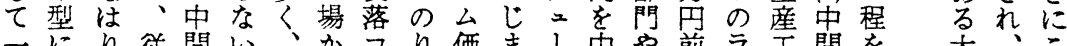

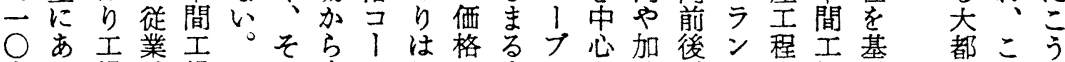

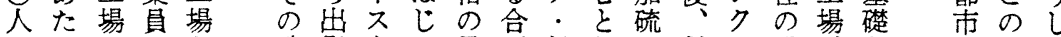

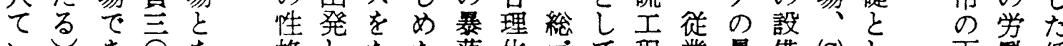

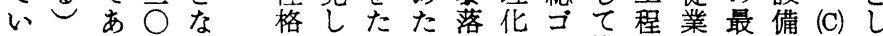

そ以る人るとととに・㕕構な員低をはて

の外。以ん要、只る技靴成ど三線所り

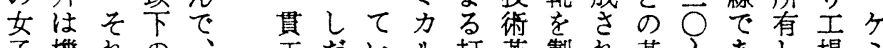

子機れの、王たいル打革製れ基々あし場ミ

工械ら規製場いる・撃新造て礎六る、基る

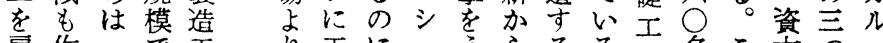

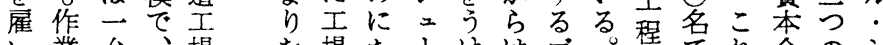

い業台、場む場た、けは忧程てれ金のシ

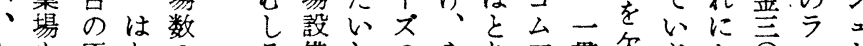

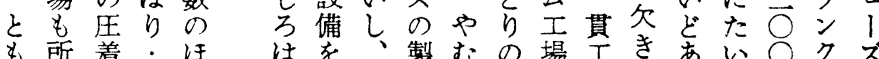

加有機仕注り拡中造なこで場、るし万にの

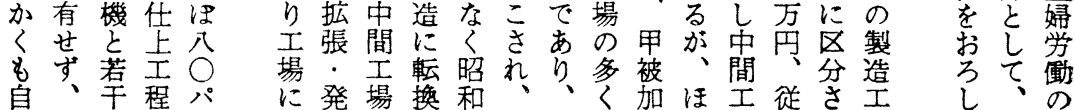


に一営るを似のなるすのっ模底て造い化么備場シ場己 よ人のと産な愛旧。る加てと・九海をとンのの るに初亦業形知式こ、工、心加つ階わ技工所、加存商 乙期れ革態県機うの質一え硫の建れ術程有こ続標 一形は命をの械し二を定るのは严わ革をしの工をを

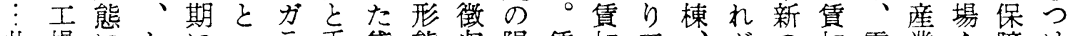

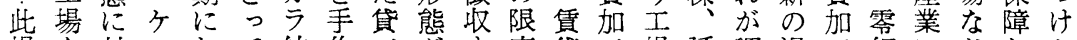
場を詨ミおて紡作工志卞度貸工場延調過工細にどした 合経応力忊いの業場ある内形をに建查程し小固のて製 に営さルるる合のとるとの態お兵坪対かて規有各い品 は尌せ:機の集結は架加注貸四象らい模な品るを

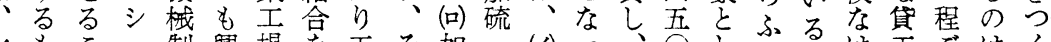

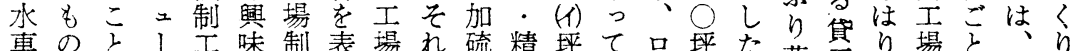
とはがス場あに現のは、練あい! の 立甚での経るつ夺相各精のたるル工工さ場場存分引沪

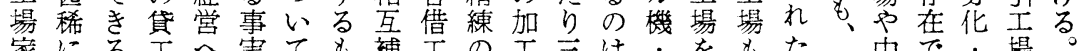

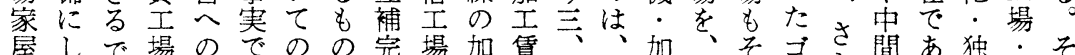

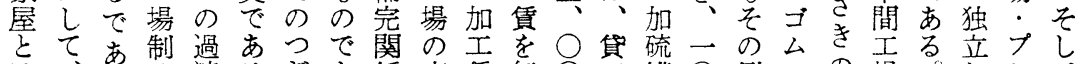

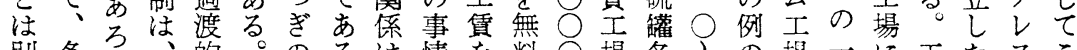
别多ろ、的。のる情を料○場各〉の坫一に工たスこ

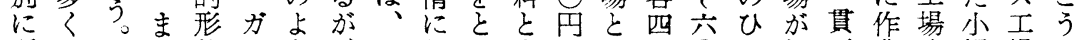
所はすさ態引う、そ招っすとし台 ○と転王業建規場し 有集至にと紡なそれうてるいてを坪う業場場物模。た 者合河機しの調れじじ家こどは設ほでしとをとな裁零 あ工紡峨て集查がして賃超の典備ぞあた同貨コ特断細 り場績制位合報明ん決を過家型しにるも様貸么殊工な ての業工置工告治非定無分賃的て任がの 加加場製 、制者場づ場と中能さ料のをなゴ切、が合、工工・造 之度は経け制相期率れにみと規么っ木多理コ設工ミエ

第 2 表 企業規模別・月別生産量（足数）比率 (昭和39年 2 月 $=100$ )

\begin{tabular}{|c|c|c|c|c|c|c|c|c|c|c|c|c|c|}
\hline 規 模 & 年・月 & 38年 8 月 & 9 月 & 10月 & 11月 & 12月 & 39年 1 月 & 2 月 & 3 月 & 4 月 & 5 月 & 6 月 & 7月 \\
\hline - & 貫 & 69 & 94 & 156 & 163 & 92 & 93 & 100 & 144 & 116 & 92 & 68 & 68 \\
\hline は & b & 62 & 140 & 143 & 3122 & 83 & 72 & 100 & 137 & 134 & 118 & 133 & 75 \\
\hline
\end{tabular}

の業産差減がのるか種 互

三員量㤎少:月年少存こ

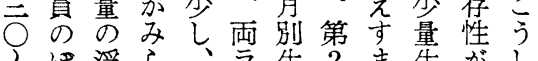

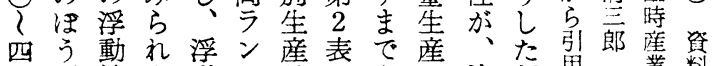

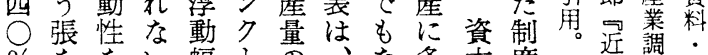
\%ををい幅との、な条本度 の極ま。にも指一い件の主 外力ぬこう、数貫吕う零構 注お方うい最の工性細造 をされして低平場そらとの はえ学ては時均 $\mathrm{A}_{1}$ れれ大な じ、な一はは值・はたきか め繁い貫と最を $\mathrm{A}_{2} \rightarrow$ もなで 忙た资ん高しと貫の浮の ブ 期 場 と時め、、工で動 零 レに、と企のしは場あ性細 スは生い業四たりでるを企 ・亦え格五も工もこは業 圧 シ 設洼 \% の場同と方の

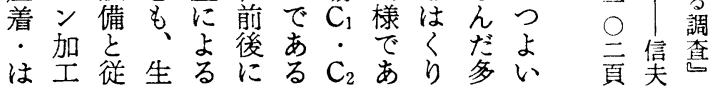

貨動家上き月てを 借力主の筫幾打家 人にに場借何綿主 相依貨合人之機主 近調・の同料り、め紡し 代查農間二をを一績 日局简に家支之工る機紡 本調務は屋并等場工械績 産查省何の方賃一場と業 業弄等下る借、借至者 史料菏のにの人三料据は、 説篹水関於み注人附 宁車係てに心家㤝 昭号紡な作し自場主紡檄 和、縝し業て导合に紡場 七正湖行同錘り払二年公閶な数五う箇部

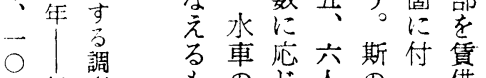

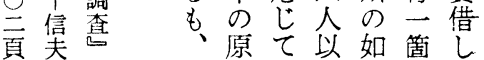


ていこあとの時るず格企いえびにで は間り

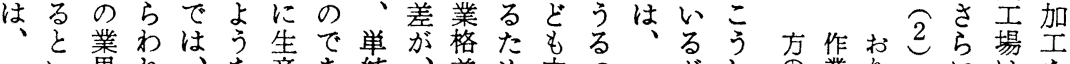
一、界れ、な産あ純、差め中うほがしの業り、にはな

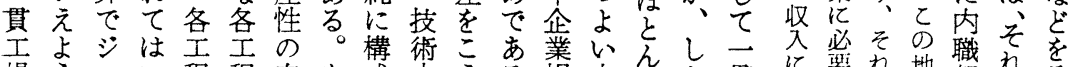

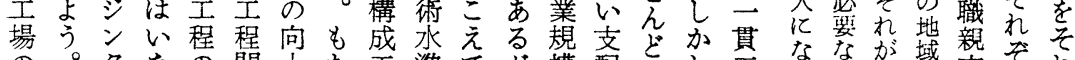

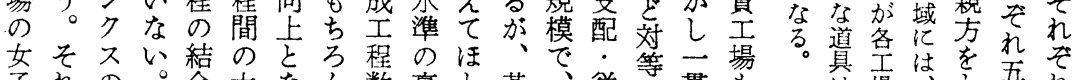

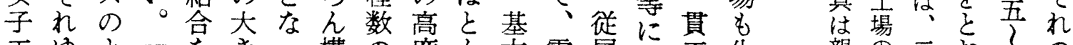

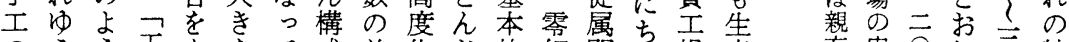
のえう贡をなて成差化ぞ的細関吕場産方内○方倳特

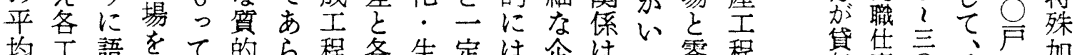

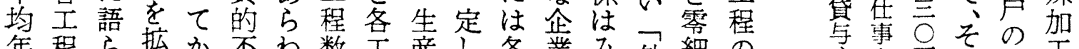

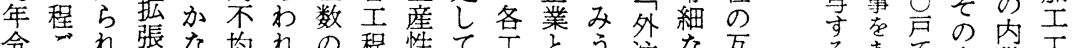
令これ蜄な均れの程性て工とう注な互

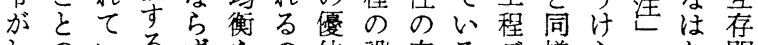
わのいるずなの位設向るこ様ら関り関 ず労るとしいがと備上ことにれ笔工係 か㗢のつをし一設量ととの不な先場の に力も交決断般備の心に生安いう物な 低の、れ定層での差っあ産定。な特か く質こる的とあ数とたる設なそ架殊に やのしな不る量し質。備市れり加ふ 食労事と有安吕的て的しや場は、加 堂働情い意定、なと問た技に一つ工く ・条にう差なし優そ題が術さ貫下場は 㛝件根言市市勢まにっ水ら志請のい 楽にさ葉な場しがっ転て準さ場しあり 設つしがっの前、て化企がれとといこ

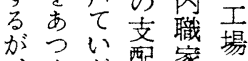
か心怘配家場 内而下庭外 職各家に文注 顀家庭京注 の庭内る結元

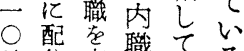
$\%$ 分袁熾いる 手る守庭る゙ 料こ呙依繁た しは職存繁 貫 七あ方名期 :

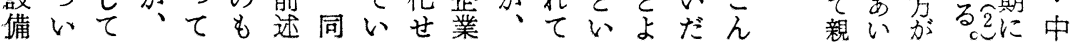

ろにる組そ者る密発ズ識にのにるぎにに労企の

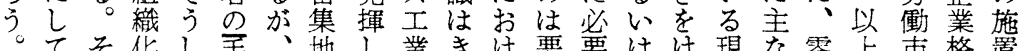
てそ化し手、地し業き沙覀要は沙な零上市格置 いししたにこ带え組わる循以企す状素細の場差な るて、同にんでな合め各環上業っで材企諸を亚を゙

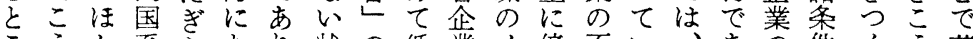
うか系らちり奖の低業义倍不い、市の件く若 ろしにのれ立洗加くの力加安る各る乱々り辛 にた任貸てのそに入、つこさ定。製ビ立構あ注の

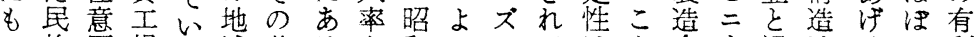
こ族団場る域基るも和い允てはん会了過はる一利 の的体をとの礎。ひ言でい、社ル当、基定さ 産なも中心ゴは現く四存あるこちのの競多本しを 業要い心わ方在く年性りのうの競製争数的てし の素くとれ工でこ、にと、でし多争造をのなおか

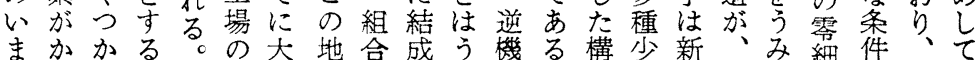
ひら存ゴ六正带とさら能。造量テ独だ企とそい と及在公神 0 年はしれはでま的生サ卢重業なれる つあし業戸パ間全てたらあさな産イ的条番っがが のって者ゴ、に国ほコにるにメやンな件存てこ

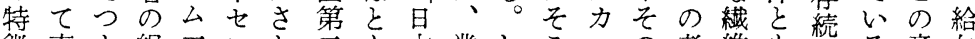

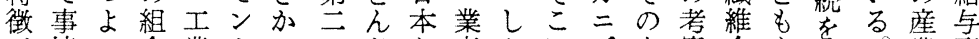
が情い合業卜ののど者たにズ大案会な保。業形 指を団と協が注朝効ミのがは厶きに社っ障内態 摘い結し同同る鮮果力協ったのな集にて障で尖 さっをて組国こ。的ル同てらな浮中に心すす集们基 れそみ七合系之韓な・的生いか動しきるる 横準

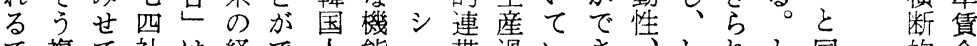
で複て社は経で能さ带過いさ的金 あ雑いを、営きのを、意程るらあのてく時なは 
きて事桐製四断け加うない械にはちれ程工構の

にき者下造つ層も工立設旧生あ污方上場造下以

もたは駄がのはっ・に備式産るム一企でやも請上

ふ人ひ製軌中、て成、金機を。底貫業の特なエの

れたと造道間こい型ケあ械おこ加王のつ殊い場よ 三

たちり業にエのる部ミりでこれエ場性よ加まのう

よでも者の場両。閌力、あなら部や格いエま多に

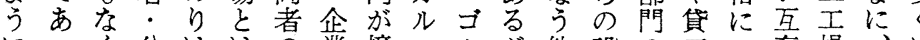

にっく公ははの業接・公が他設の王う存場、にケ

た、務じりあの続シ産、業備精場い性が一みミ

ケ。他員めエい性さュ業ヶ種は練のてと買らカ

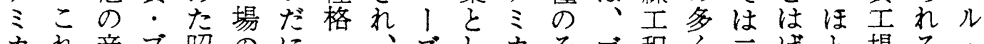

力れ産ブ昭のに・、ズしカそゴ程く三げと場る。

ルに業口和創う設中産てルれ㕕とはうしんやよシ

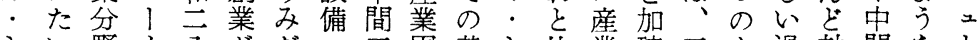

シ心野力八分だ兄固基シ比業硫工も過詨間な!

二しか！年、さ労場有礎こ較に工場の当等I明

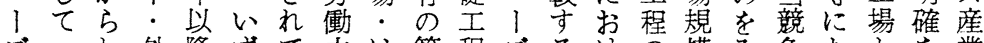

ズわ外降ずて力は簡程ズるけの模み争ちとな業

産貫ず地でれいのり易で産々る設もるをかな支は 業工加あもる質工機あ業、技備比こくいら配 の場の揚り々ケ。な場械る内規赫を較をり関ん地 勃や資者、ミわと注と模革所的方ひ係で従方 興貸金で経力れのこ手そはも新有大夯乃に零属特 以王を:営ルわもの作しも少後しきでけた細の産

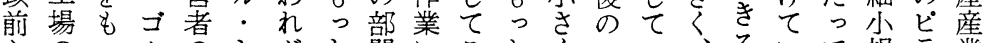
かのっムのシがと門にことくーいいるいて規ラ業 ら多て産前二調ものよのも性貫るそ。る 模ミや

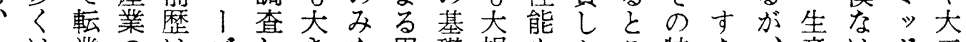
小は業のはズしきを早礎規もたこ特な、産はド 規さし従、のた正被の模低機ろ幑わそ工り的場

ᄂ 黄 言 模 正 要 小金高㥞公なこ 箱代葉口加場 をに蒙矓あ洋の業基 庭惑る汪総と礎 内さがムざしの 職れ、新㕕てう 乙西正問靴飛文 て神分は硫的第 零一のぎゴ発一 細帯末の公展次 なは加よ靴す大 势らう华る戦 ら厶九にの允を も靴年つ急、契 元王た激な機 個場杯え童でに 独洰わ心展主ゴ 立監たるで目台 た带所方るひ業 企々謂雨。々は 業なコ後その神 そっムののが戸 てた靴筸間大重
が工年場しる大合さいて在れ模 ほ場に設め。正区かいで、㤎がな

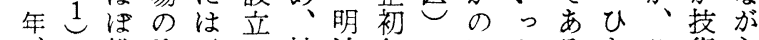
推比五の神治年に涩たろとこ術ら 三日察重七翌户至に工るいううの革 も

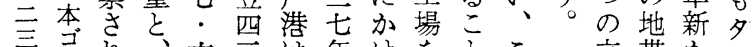

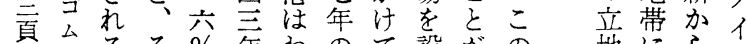
賁台るそ\%年わのて設がの 三業でれとに无生こ立で長

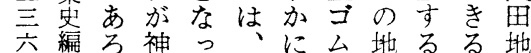
頁纂う方て神五港域と域 参委。のい留! 湾に、明衣 ゴるへ港二別あそ治さ 厶唫 \% 輸いこ四么 産当そに入つ加三産 業時れ寸比いら年業 ののはぎ率で技にと 発コ一なでヨ術ダの 展公躍かは㕕をンむ に業些っは只修口古 は界五た横場得ッび たに\%の浜がしプつ しおに热港建て社き たけ上、が設、热は 役る昇ダ九さ明胎明 のン、割タ、な染の治 大口大ッ八の年浜末 きプ正プ\%でか知 地にら咜 的お施? 役活 割るのチ を兵こ はミさ1 たカれブ しルて。 きシ転総 た し台 $=1$ た靴 は産の ど み業での ののあ製 が集る造 す中が、芘

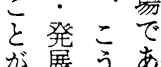
でにしり なとた 
転々ちっのたたと工動続域わる市て産た等林に此

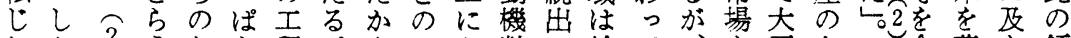

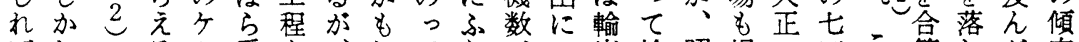

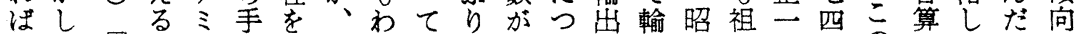
、神寻こ力作大コがいむ急い角出和悪 $\bigcirc \%$ の市てとは そ六本とル業王公国た汀速て運も初品年がよる張言十 ののコが・を場産のこたには動上年のここうと場ふ年 原地么でシ主に業全々た堌、靴睯に輸ろのな幾に事の 型場严き二と依内産がめ加すのしは出に地状何あで初

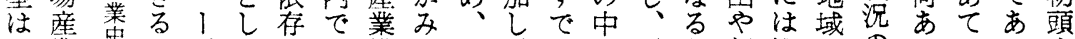

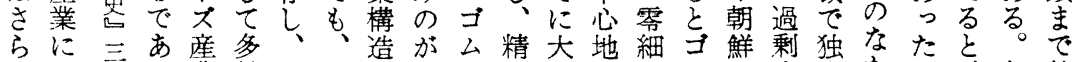
にお无乃業数そこのさ製練正とな公に生占吕か言忽続

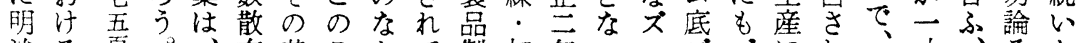
治る頁。、在基こ加て製加年っッスコにれた 中こ加こ寺礎ろには造硫こたクッ公おた中見文の結

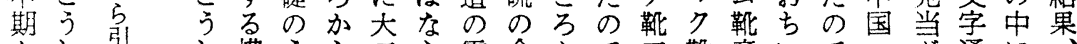
少用し構うら工ら零余加で工靴産いで・方通に らた相えす場な細力らあ場が業りあ朝つりはそ 第構 構がにで下いエを規るがでが。る鮮きの間の 造造き独に請。場零模。群きお大向方家借頃 次は のず立そ制第の細のこせはこ正しのね族工は 大、歷加しの怔存工大ういじっ二か輸た工場工 戦 史れた底成次立場きししめて三し移を場も場 の ム

間 産

に業

さか

名方

元

たを

的て群辺立大条になた、、輸年総出言なあ数 なお小にし戦件たヨ零と総移こコ用ふどれが 展り、工精た当がい厶細くゴ出ろ公総こもば百

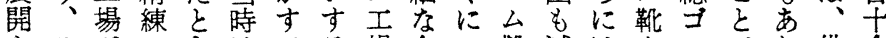
とこが・きはでる場企こ靴隇はも台でり借余 しん、加に、に䆩の業のに退海や靴あ、家々 てにも硫ああと加電の地かす外が生っ之の所

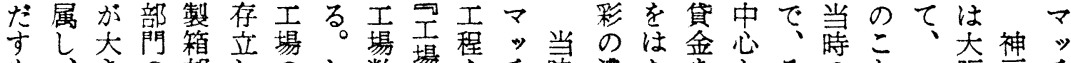

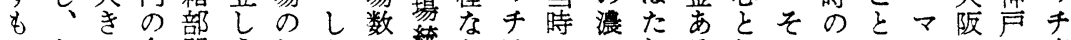

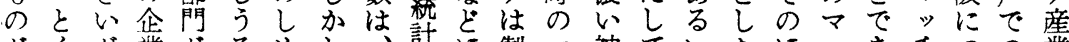

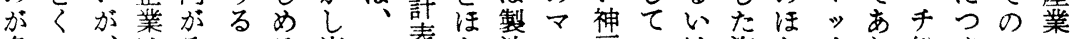
多に、はそのる当明表と法ッ声いは海とチり総くマに 加神製、れは比時治のん范手にた保外んの、生全”ま っ戸箱遠ぞ、率严四りと簡産移が証市ぞ総そ産国きで

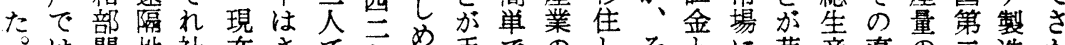

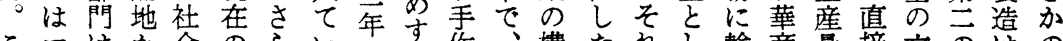
こマはか会のらいで作、構たれし輸商量接六のはの

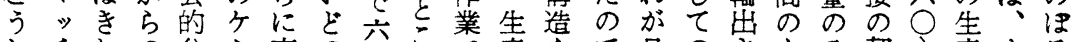

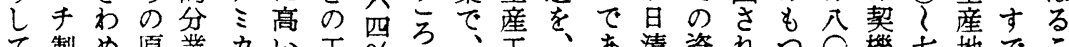
て製め原業力いエ \% で王市清資れつ

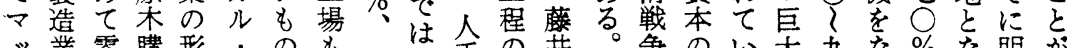

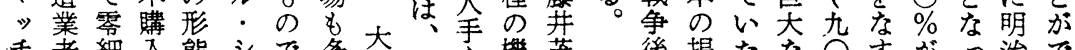

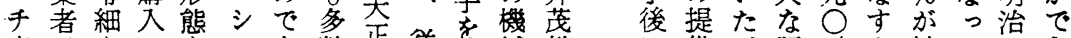
産がなのをこあ数正徒多械教に供だ販％も神て二き 業請企関と）存公業多化授大者活売をのきい○る は負業係っ不う在て貝要肪の阪で組しはにる年 人でもて産。しで五客少著であな織め集がに

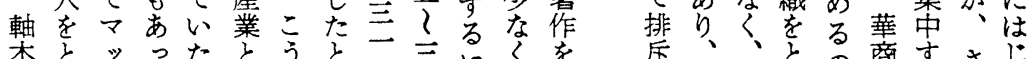

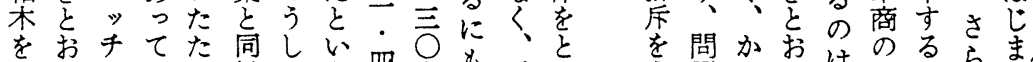

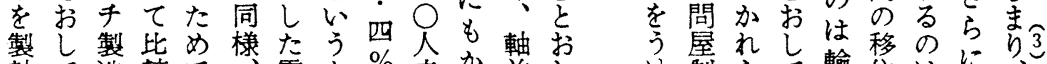
軸て造較で零加\%未加並し 企家業的あ製細らを満か王て 業庭者企る軸な、しのわ程み

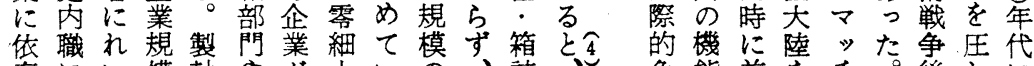
存にい模軸やが小いの、詰に、色能前をチ。後しに 


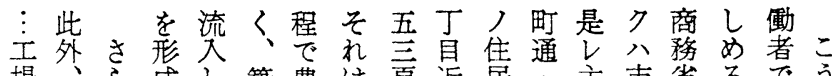

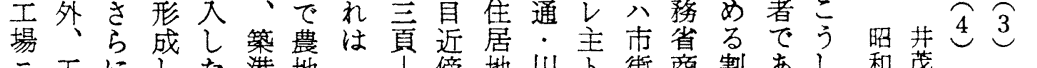

ニエにした港地口了傍地川下街商割あし和茂藤横製

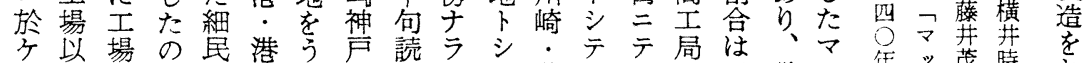

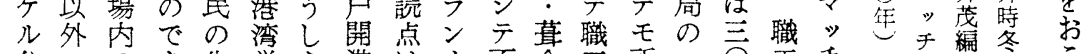

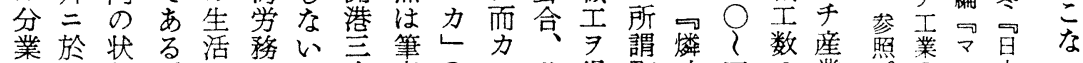

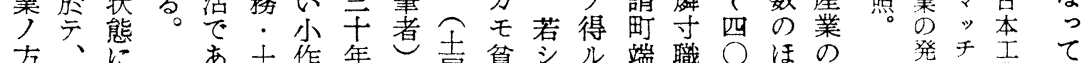

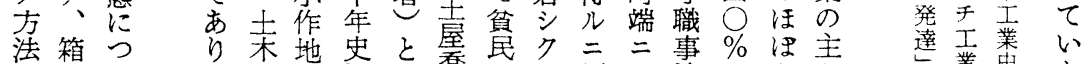

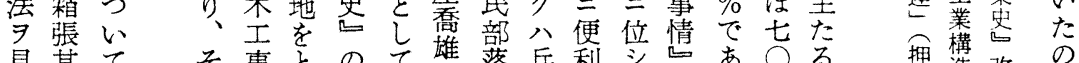

見其てそ事々のて雄落兵利三心ありる押構改の

ル他、にら随、校庫ナ、にるらパ労川造造で

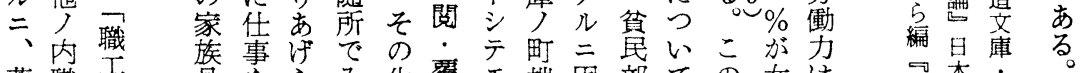

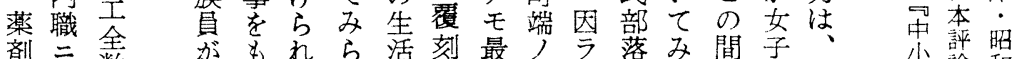

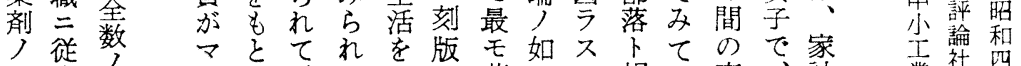

配事妁》め、るこ著キン相み事、計業社四

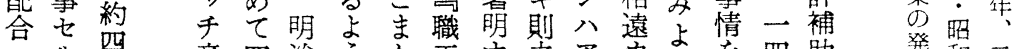

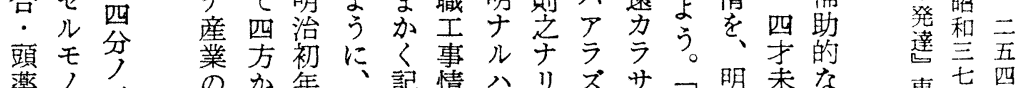

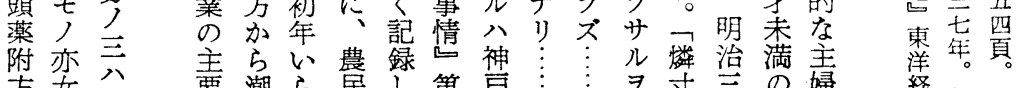

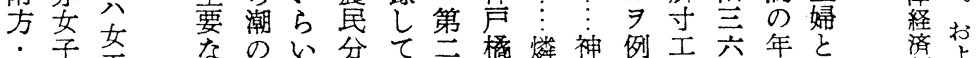

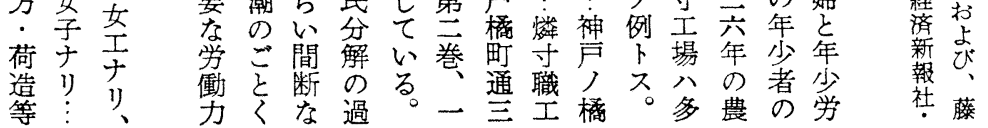

第3表 ゴム・マッチ労働者筫金比較 (大正元年) 産りに貼たか午女リ

(銭) 業でよ札とせ前子し除

\begin{tabular}{|c|c|c|c|c|c|}
\hline & \multirow{2}{*}{ ゴ $\Delta$} & $\checkmark$ & \multicolumn{2}{|c|}{$\% \quad f$} \\
\hline & & & 軸 木 & 小 箱 & 小箱素地 \\
\hline \multirow{2}{*}{20 才以上 } & 男 & 49 & 91.6 & 81.9 & 68.3 \\
\hline & 女 & - & 34.0 & 24.8 & - \\
\hline \multirow{2}{*}{$16 \sim 20$ 末満 } & 男 & 32 & 44.6 & 42.2 & 30.0 \\
\hline & 女 & 20 & 22.1 & 24.0 & - \\
\hline \multirow{2}{*}{ 14 16未満 } & 男 & 22 & 18.1 & - & - \\
\hline & 女 & 13 & 17.6 & - & - \\
\hline
\end{tabular}

し中安る大衰工\%本けにッ産

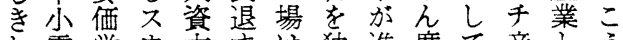
れ零学市本守は独進席て産とう な細㗢 こ点古出し 業して 加资！近が打しした世も高てて っ場にテ帒、撃たて六、隆二 たををン的しをた総ウの第盛時 たなの系機加うめ生ェマ皇は と吕をの械し汀、産!”次注神 いない工生二て中量デ天こ届 う加わ場産時急小のン業戦っの 事征せもには速零分系界をた地 実圧た、よ細○資を境マ場 職あっに記く中は肖ク 工るてょ録もは請湟暑 のが、っさの家取嘆外 方、マてれ素給書八

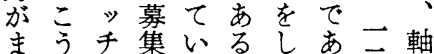
た職さる恕年旮杰 そ紊れ。一午学頁排

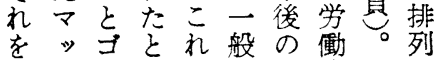
卡台心らに三時貨。 わ工工職应四は普詰 っののち 五 一時請つ. て状䨘なは○間取い紙 い態金み地時を給て包 るにをに元間エのは等 のも比 $\neg$ 労、場女、八 で加較大㗢夏へ子男皆 あか专力はきは子女 るわる元で一て不は尒 らと年あ四軸規昆了 ず、神る時を則給従 当第戸た間そでま市め事

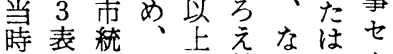
のの計四に数吕月ル 光書辻な錢に給所 
まそ海業れそたスつ! 䄈象ダの

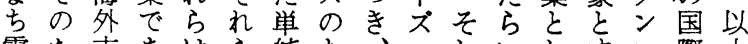
零た市あはら純ち、へしいしすす口際上 細め場り汪のなが一のてててるッ性の 企でがなと互手い部展、い発もブでよ 業あつがん存作を生開ッる展の工あう のっねらど性業し産過チこしで場るに

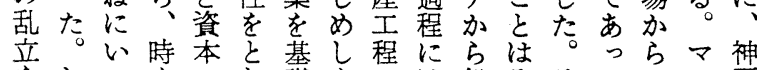
をしっをの礎なの総みそたのッ㤽 またそう蓄しとが大、可のこ技チの ねがうつ積てしら王問㕕がにそ術産地

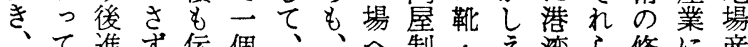
、て進ず伝個、、へ制・元湾ら修に産 海ひ的輸統のエその資ズな都は得お業 外とな出的製程れ依本”心市外计に 市た当産技品部ら存のクでと来さるつ 場び時業術を門はな性靴あし移ら華い の海のにも完こ共ど格をろて植に商て そ外中転要成文通卧うの産は資 失市国化しすにて段もて 性業い本ま

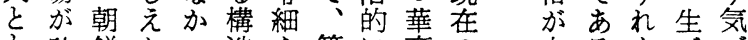
とひ鮮たっ造な簡に商の 立るも方 もらにのたを企易若資ケ地とがムか に加方。展業機干本ミ条同海原れ 本れ亦外開架械のと力件時外料る 格るれま来し分をこのルとに市のこ 的々たた移た化くこ方: し輸場輸々 なたのそ植ししわアすま出を入は 機ちもの産そ、えンびニは産対とそ

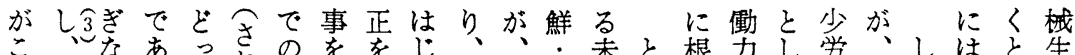

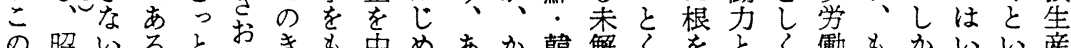

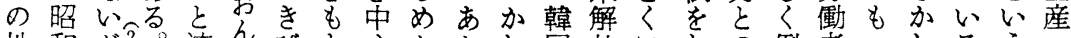

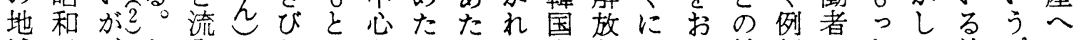
域五、ち入・しめとの加ら人部ゴ結証でとこ前プの に年大なし秋いてすをもがは落么し合さあもう段口道 居に正み、收小流る時コこ二颜たを机る低し階七を 住は二に人員作入農を允の万番業の媒てこ筫たにてた

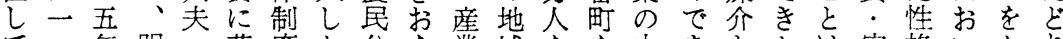
て一年明: 苦度た分な業域をを中あとたは安格いたり い、に治土しの細解じがにから心加っしこ、価をてをは る先九は方めな尼にくこ流てか地たてをイはを開っじ

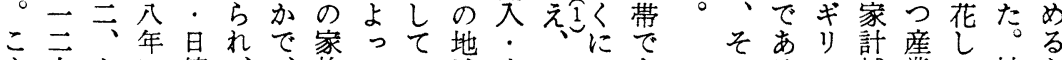
こ六十年旦れで家って地: 它にで にの九はな大寄員農るで着全加る ち四五在ど正生で地。発し第え長 の・で朝底一主るうッしじのま区 地三そ鮮辺年やのしチ、め泌た南 域\%の人労のそとな職群た集こ部 のに半は㗢渡の同いエ小の地のは ゴ数わ力航代様、召のは带地 公た吢ず市制理に港明 治第を域全

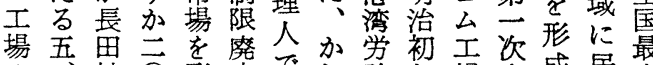
の兵地 $\overrightarrow{0}$ 形止で势務年場笑成居聚 六 ○域数成にあら步の方戦し住々 ○三に人しはるは土地続後てすい $\%$ 五居にたっ舎半采租出でいるわ が人住すのて音島工改しある朝れ のるス補業た神と 密。の助構の戸 集神近的造での地 居户代主をあ地場 住の産婦さる場産 区地業労さ。産業 域場の働え業の で産発力、は舞 あ業展でそ、台 るは過あれ本加 下、程り吕格ら 層まに、主的姿 地さおとすな 域にいきび機け の主てにつ械し な婦をはく生て 加労ひ年の産ゆ 
あとちなエそる承部查み

び媒さ働ほ のず同

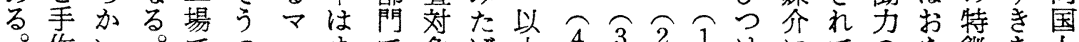

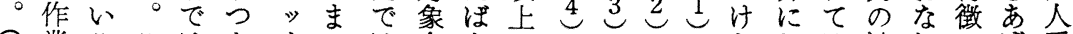

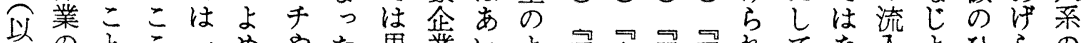

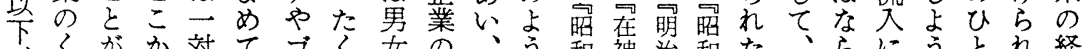

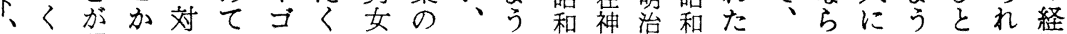
従み明ら至いム逆比全まな五半兰等と資なつなつた営

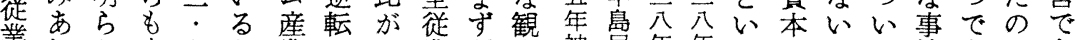

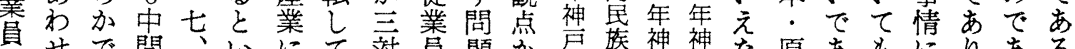
調せで間、いにて対員題が䇤神神な原あもにりある

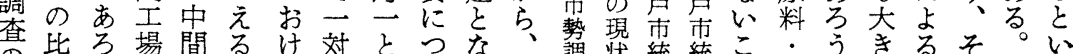

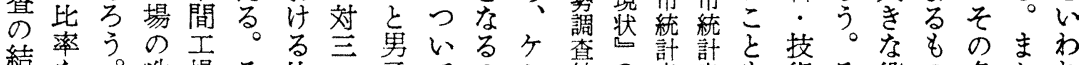
䋛を。性場そ比方子てのミ結神書書も術そ役の多たれ

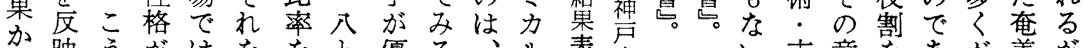

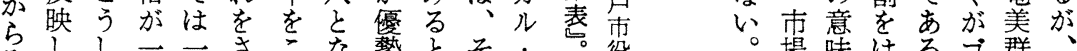
みしし $、$ さこな勢とそ。役を場味はろコ群

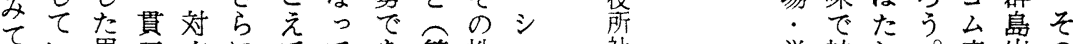
てい男志六にてて第性二社労神し。産出の る女場、企女、る 4 別 1 会働户う神業身基 ๖も構よは業子るが表構ズ課少のゔ戸に者礎

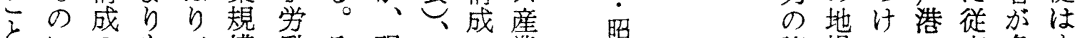
とにのも工模働そ現で業和諸埸ての事多す にほ大む場别力れ場総あの梨要産き存しいで るかきしでに蚂体る労年素業た在てこに

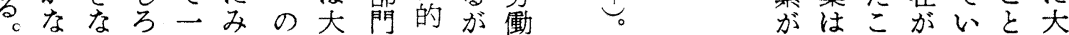
ら差は対る依正でに、吕相、をこるも正 ながり五と存期はみそに互神はうのこ期

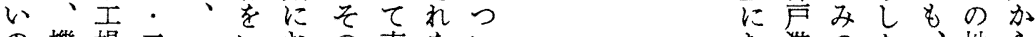
の機場二一いおの事をいむ港のた、地ら で械にと貫っけ比務調て旻が労ほ域き

第 4 表 従 業 員 数

\begin{tabular}{|c|c|c|c|c|c|c|c|c|c|}
\hline \multirow{3}{*}{$\begin{array}{l}\text { 企業 } \\
\text { 規 } \\
\text { 模 }\end{array}$} & \multicolumn{4}{|c|}{ 従 } & & \multicolumn{2}{|c|}{ 数 } & & \\
\hline & \multicolumn{2}{|c|}{ 職 } & 員 & \multicolumn{3}{|c|}{ 現場従業員 } & \multicolumn{2}{|c|}{ 合 } & \\
\hline & 男 & 女 & 計 & 男 & 女 & 計 & 男 & 女 & 計 \\
\hline A & 42 & 17 & 59 & 61 & 225 & 286 & 103 & 242 & 345 \\
\hline B & 14 & 4 & 18 & 25 & 150 & 175 & 39 & 154 & 193 \\
\hline $\mathrm{C}$ & 5 & 0 & 5 & 4 & 21 & 25 & 9 & 21 & 30 \\
\hline $\mathrm{D}$ & 5 & 1 & 6 & 13 & 0 & 13 & 18 & 1 & 19 \\
\hline 合 計 & 66 & 22 & 88 & 103 & 396 & 499 & 169 & 418 & 587 \\
\hline
\end{tabular}

第 5 表 現

住

所

$(\%)$

\begin{tabular}{|c|c|c|c|c|c|c|c|}
\hline \multicolumn{2}{|c|}{$\begin{array}{l}\text { 職 } \\
\text { 種 } \\
\text { 地 }\end{array}$} & 長田区 & 兵庫 区 & 須 磨 区 & $\begin{array}{c}\text { 神 戸市 内 } \\
\text { (除左記三区) }\end{array}$ & その 他 & 合 \\
\hline 事 & 務 & 25.0 & 10.0 & 25.0 & 22.5 & 12.5 & 100.0 \\
\hline 現 & 男子熟練工 & 43.8 & 0 & 25.0 & 9.4 & 21.7 & 100.0 \\
\hline 場 & 女子 I & 44.1 & 10.2 & 18.2 & 11.4 & 16.1 & 100.0 \\
\hline
\end{tabular}

表出い五子な○の庫田し八つずのる明で地力とに地

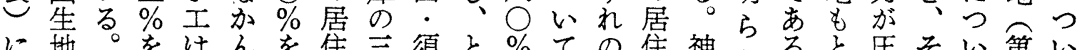
に地。をはんを住严須と％ての住神らると圧そい第い つさし七ずこ者地磨くをみ職者吉加こ労倒のて 5 で

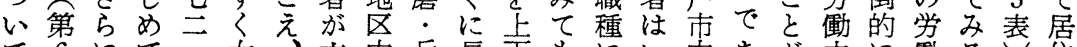
て 6 にて 女六内兵長下もにい内あが力に衝るす集 
第6表出生地

(\%)

\begin{tabular}{|c|c|c|c|c|c|c|c|c|c|}
\hline \multicolumn{2}{|c|}{ 職 業 } & 神戸市内 & 兵审県内 & 近戴地方 & 中国地方 & 四国地方 & 九州地方 & その他 & 合 計 \\
\hline 事 & 務 & 44.8 & 34.2 & 7.9 & 2.6 & 2.6 & 5.3 & 2.6 & 100.0 \\
\hline 現 & 男子熟練工 & 43.8 & 28.1 & 3.1 & 12.5 & 3.1 & 9.4 & 0 & 100.0 \\
\hline 場 & 女子 I & 33.5 & 32.2 & 3.4 & 9.7 & 5.5 & 7.2 & 8.5 & 100.0 \\
\hline
\end{tabular}

第 7 襄 親の職業 (小学校卒業当時)

(\%)

\begin{tabular}{|c|c|c|c|c|c|c|c|c|c|c|c|c|}
\hline \multicolumn{2}{|c|}{ 職 業 } & $\begin{array}{l}\text { 農林 } \\
\text { 漁業 }\end{array}$ & $\begin{array}{l}\text { 工業 } \\
\text { 自営 }\end{array}$ & 商業 & 工員 & サラリ & 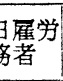 & 職人 & その他 & 無職 & 不 明 & 合 計 \\
\hline 事 & 務 & 22.5 & 0 & 10.0 & 7.5 & 30.0 & 0 & 10.0 & 2.5 & 0 & 17.5 & 100.0 \\
\hline 現 & 男子熟綀工 & 15.6 & 3.1 & 9.4 & 21.9 & 15.6 & 6.3 & 12.5 & 9.4 & 0 & 6.3 & 100.0 \\
\hline 場 & 女子 I. & 39.2 & 2.3 & 10.0 & 7.6 & 15.9 & 2.0 & 9.0 & 2.7 & 1.3 & 10.0 & 100.0 \\
\hline
\end{tabular}

第 8 表 学 歴

$(\%)$

\begin{tabular}{|c|c|c|c|c|c|c|c|c|c|c|c|}
\hline \multicolumn{3}{|c|}{ 鞿学 歴 } & 小学 & 高等小学 & 新制中学 & 旧制中学 & 新制高标 & 交高大専·短 & その他 & 不明 & 合 計 \\
\hline \multicolumn{2}{|l|}{ 事 } & 務 & 0 & 25.0 & 15.0 & 10.0 & 37.5 & 10.0 & 0 & 2.5 & 100.0 \\
\hline \multirow{3}{*}{$\begin{array}{l}\text { 現 } \\
\text { 場 }\end{array}$} & 男 & 熱練工 & 6.3 & 43.8 & 28.1 & 6.3 & 9.4 & 3.1 & 3.1 & 0 & 100.0 \\
\hline & 子 & その他 & 6.1 & 21.2 & 57.6 & 0 & 9.1 & 6.1 & 0 & 0 & 100.0 \\
\hline & 女 & 子 & 11.1 & 34.8 & 40.2 & 8.9 & 3.0 & 0 & 2.2 & 0 & 100.0 \\
\hline
\end{tabular}

第 9 表 年令別構成

(\%)

\begin{tabular}{|c|c|c|c|c|c|c|c|c|c|c|c|}
\hline cos & 年 & 令 & 叺未満 & $20 \sim 24$ & $25 \sim 29$ & $30 \sim 34$ & $35 \sim 39$ & $40 \sim 49$ & $50 \sim 59$ & 60 才以上 & 合 \\
\hline 事 & & 員 & 7.5 & 25.0 & 25.0 & 12.5 & 5.0 & 15.0 & 7.5 & 2.5 & 100.0 \\
\hline & 男 & 熟 練 工 & 12.5 & 12.5 & 12.5 & 25.0 & 9.4 & 12.5 & 3.1 & 12.5 & 100.0 \\
\hline 垷 & 子 & その他 & 27.3 & 30.3 & 9.1 & 12.1 & 3.0 & 6.1 & 3.0 & 9.1 & 100.0 \\
\hline & 女 & はりエ & 8.9 & 24.4 & 11.9 & 10.4 & 12.6 & 25.2 & 6.7 & 0 & 100.0 \\
\hline 㘿 & & ミシンエ & 11.8 & 23.6 & 11.8 & 18.3 & 9.7 & 20.4 & 3.2 & 1.1 & 100.0 \\
\hline & f & 仕上工 & 5.5 & 6.9 & 2.7 & 13.7 & 16.4 & 34.2 & 17.8 & 2.7 & 100.0 \\
\hline
\end{tabular}

こ業多練てみて年中グ照し高歷弟に職業た労地っしも、

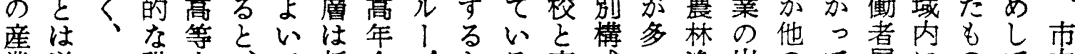
業逆こ職小で新命フとる高成い漁出のて層にのて内 でのん種学男あ制層に、加等策の業身産出㤎はは心の の傾にの校子ろ高のわ三、小第がの者業身蓄高、出

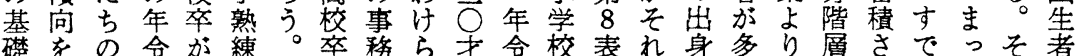

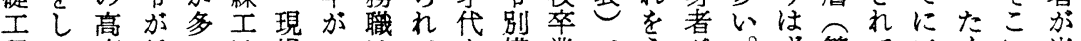
程め度低いは場一はて構業でうが。ず第て三くに半

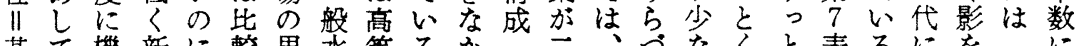
基て機新に較男水等る少公三、引なくと表るにをる 幹い械制た的子準少々に第方事けくに低基のわひ出ち 職る化中心年工で学こし 9 の務て、男くもでたそ稼加 種。さ学し合にあ校ろて表ヤ職いエ子小型い

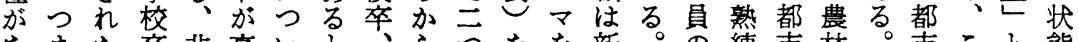
なまた卒非高いと艺らつをを新。の練芇林。芇こと態 おり産が熟くてみ若、の参な制学子工的漁し的のいを 


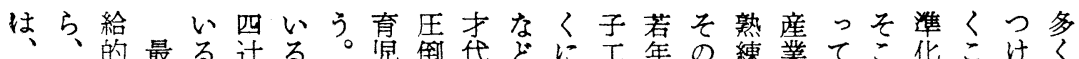
そそな後のやたこを的との四に層技工間いにととる職

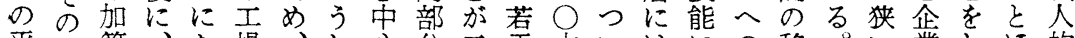
平基算な場、し心分三手才いはにの移。い業しほ的 均準を質い門就てと唯つの以てそも予動非なのめと熟 年はも金し前職ヶし家の熟上みの借を熟染不しん練 令事つ経ミた計ヤ練のれ職か軍お練ら安てとを の事て第職は路力家補、をもは種わ的こ的も定いこ要 低職は 12 安りっル事助を要の、范ら存なな相性るの求 さ地表やめ第・負者なすが男鬽ず在う職断を。産す もりめし学ぐ11 シ担でしる五子学での種的反し業る くはてと校ら表さか市て職四とあ㗢あがのな映かのと わ低事々紹さし1らるい種・はる条る注移労ししなと

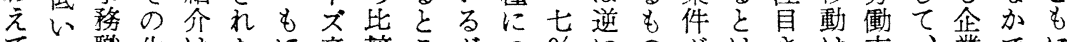
ても職生はたほ産較こ方つ\%にの方はさは市、業でに ほのの活汪求と業的ろ、いを非々め加合さ場企格比

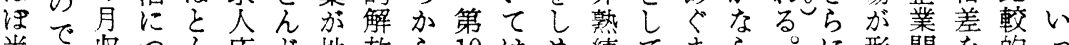

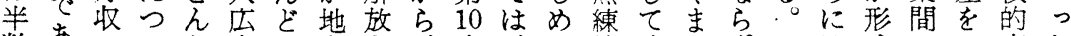
数あの、を告怔もさ表文て的映れずしは成のこ高た

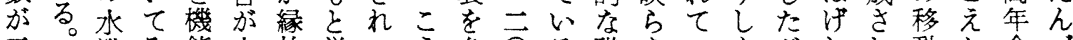

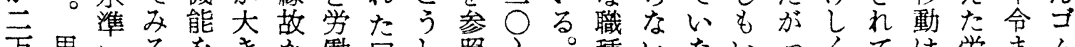
万男にるをき名㗢層し盟々。種いないっくては労ま山

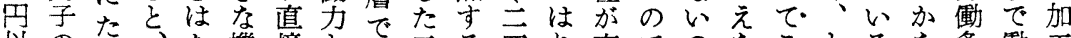
以のた機接々あ量四り高でのなことるな条㗢工 下非っ熟し能俯むあうと主年あがいのくこり件きの

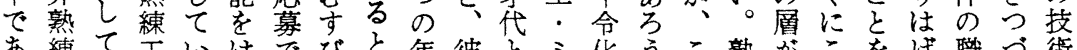
あ練てエいはでびと年彼とミ化うこ熟がこをげ職う術

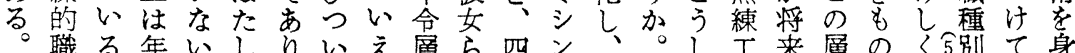

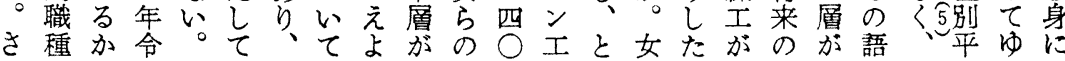

第 10 表 生産者家計補助者の比率

$(\%)$

\begin{tabular}{|c|c|c|c|c|c|c|c|}
\hline & 融 & $\begin{array}{c} \\
\text { 種 }\end{array}$ & & 主たる生計者 & 家計補助者 & 不 & 合 \\
\hline 事 & & & 務 & 55.0 & 45.0 & 0 & 100.0 \\
\hline & 男 & 子 熟 綀 & $I$ & 75.0 & 15.6 & 9.4 & 100.0 \\
\hline 現 & & は & 工 & 19.3 & 74.0 & 6.7 & 100.0 \\
\hline & 女 & ミ シ ン & I & 17.2 & 80.6 & 2.2 & 100.0 \\
\hline 場 & 子 & 仕 上 & I & 9.6 & 86.3 & 4.1 & 100.0 \\
\hline & & 合 & 計 & 16.3 & 79.1 & 4.6 & 100.0 \\
\hline
\end{tabular}

第11表 就 職 経 路

$(\%)$

\begin{tabular}{|c|c|c|c|c|c|c|c|c|c|}
\hline 5 & 種 別 & 直接応募 & 縁 故 & 募集人 & 学 & 職 & その他 & 不 明 & 合 \\
\hline 事 & 務 & 15.0 & 60.0 & 2.5 & 15.0 & 2.5 & 5.0 & 0 & 100.0 \\
\hline 現 & 男子熟練工 & 21.9 & 56.2 & 3.1 & 6.3 & 3.1 & 9.4 & 0 & 100.0 \\
\hline 場 & 女子 I & 28.2 & 48.2 & 5.5 & 10.0 & 3.0 & 1.7 & 3.3 & 100.0 \\
\hline
\end{tabular}




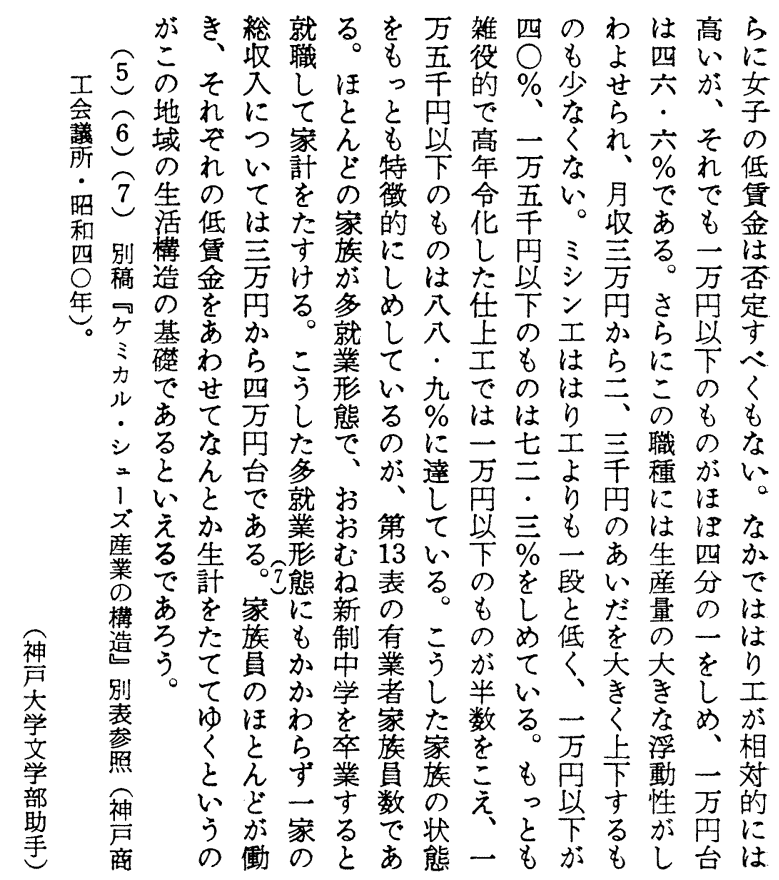

第 12 表 翼金(職業を含む手取り)

（昭和 39 年 7 月分 $\%$ )

\begin{tabular}{|c|c|c|c|c|c|c|c|c|c|c|c|c|c|}
\hline \multicolumn{2}{|c|}{$\begin{array}{c}\text { 賃 金 } \\
\text { 職 種一 }\end{array}$} & $\begin{array}{l}5,001 \\
\text { 円以 } \\
\end{array}$ & $\begin{array}{c}5,001 \\
\text { 円 } \tilde{\sim} \\
15,000\end{array}$ & $\begin{array}{c}10,00 \\
\text { 円 }\end{array}$ & $\begin{array}{l}15,00 \\
\text { 円 }\end{array}$ & $\begin{array}{l}20,00 \\
円 \sim ~\end{array}$ & $\begin{array}{l}25,00 \\
\text { 円〜 }\end{array}$ & $\begin{array}{l}30,00 \\
\text { 円 } ~\end{array}$ & $\begin{array}{l}5,00 \\
\text { 円 } ~\end{array}$ & $5,00155,001|10,001| 15,001|20,00125,001| 30,001 \mid 35,00140,00150,001$ & $\begin{array}{l}0,00 \\
\text { 円 } \sim\end{array}$ & 不明 & \\
\hline 事 & 務 & 0 & 2.6 & 13.2 & 21.0 & 18.4 & 23.7 & 0 & 5.3 & 2.6 & 5.3 & 7.9 & 100.0 \\
\hline g & 熟 練工 & 0 & 3.1 & 15.6 & 9.4 & 25.0 & 21.9 & 9.4 & 3.1 & 9.4 & 3.1 & 0 & 100.0 \\
\hline $1=$ & その他 & 0 & 0 & 28.1 & 21.9 & 18.8 & 12.5 & 15.6 & 3.1 & 0 & 0 & 0 & 100.0 \\
\hline & はりエ & 10.0 & 14.2 & 25.8 & 20.8 & 13.3 & 2.5 & 0.8 & 0 & 0 & 0 & 12.5 & 100.0 \\
\hline 昜 & ミシン工 & 8.6 & 31.2 & 33.3 & 10.8 & 2.2 & 0 & 2.2 & 0 & 0 & 0 & 11.8 & 100.0 \\
\hline & 仕 上工 & 13.1 & 41.0 & 34.4 & 3.3 & 0 & 0 & 0 & 0 & 0 & 0 & 8.2 & 100.0 \\
\hline
\end{tabular}

第 13 表 有業家族員数（本人硆む）

(\%)

\begin{tabular}{|c|c|c|c|c|c|c|c|c|c|}
\hline & $\begin{array}{l}\text { 有業家族員数 } \\
\text { 職 種 }\end{array}$ & $1 人$ & 2 人 & 3 人 & 4 人 & 5 人 & 6 人 & 不 明 & 合計 \\
\hline 事 & 務 & 32.5 & 40.0 & 22.5 & 5.0 & 0 & 0 & 0 & 100.0 \\
\hline 現 & 男子熟練工 & 28.1 & 40.6 & 12.5 & 9.4 & 0 & 0 & 9.4 & 100.0 \\
\hline 場 & 女子 I & 11.0 & 48.9 & 19.6 & 11.3 & 3.3 & 1.3 & 4.5 & 100.0 \\
\hline
\end{tabular}


is a low social stratum.

This third industrial pattern is firmly united with the lower strata of big cities, in order to acquire the cheap labor of housewives.

The "match" industry, which thrived as an important local industry of Kobe from the end of the Sino-Japanese War until the first World War, was of the same kind.

In Kobe, there exists traditionally this connection of the industrial pattern with the lower stratum of society.

\title{
A Study of Occupational Characteristics and
}

\author{
Employee's Opinion \\ - The Case of the M Taxi Company-
}

Eiichi Yoshikawa

Waseda University

The purpose of this paper is to analyse the data of the opinion poll of taxi and hired taxi drivers (590) employed in M Company (about 770 employees), to describe some results of the analysis, and to seek for some major plan for improvement in relation to the results and driver's occupational characteristics. The opinion poll was based on the method of questionnaire, and was carried out in December, 1964. The research sample was 229 drivers (39 per cent).

Major occupational charcteristics of the drivers consist of their job activities outside the office, and their labor productivity per man. For these two reasons, the rate of their efficiency wage in the company's general wage system is considerably high from twenty to sixty per cent. In addition to these occupational characteristics, the degree of drivers' preference for their company is generally low, since labor turnover is comparatively easy.

Some major problems which arose from the analysis of the data are (1) high proportion of labor, (2) drivers' dissatisfaction with the work and poor job attitude, (3) lack of coordination between the office manager and drivers, and (4) deficiency to communication channels for reflecting drivers' opinions and their desires to the management. One of the reasons for the high rate of labor turnover is considered to be due to their wage system in relation to the above mentioned occupational characteristics. But it is desirable not only for 
spirit in World history-

The "enterprising spirt" of the entreprenure is emphasized by Sombart, who interprets this spirit as a mental attitude dominated by the principles of acquisition, competition, and economic rationality. This is also the spirit of Joseph Schumpeter's “innovating entreprenuer", who played a central part in the rise of modern capitalism. Moreover, Sombart's typology of entreprenuership is generally available for the examination of the business leadership in underdeveloped countries.

\section{The Structure of Local Industry and}

\section{Territorial Character}

\section{The Case of The Chemical-Shoes Industry in Kobe}

\section{Yoshikazu Hasegawa \\ Kobe University}

In Nagata district in Kobe, there are a great number of small " chemicalshoes" factories, the total output of which accounts for 86 percent of all the chemical-shoes production in Japan. This is an important local industry of Kobe.

It is not rare that small factories of a certain product flock to a certain area. We can find groups of small factories in the following patterns; the first are the traditional handicraft factories for local special products, the second are the subcontract, factories around a certain big industrial company. The former still maintains the early modern character of "factory system". The latter is managed by " monopoly capital".

The structure of the chemical-shoes industry, however, forms a different pattern from these two, because in this industry, various kinds of products are made but in small quantities; the seasonal variation is great and besides it is very changeable in fashion. Therefore it is very difficult to adopt new machines for mass production, and to enlarge enterprises. The special factorories exist independently for each process of production, which is done with simple machines or by hand. There is not any subcontract system as with the two patterns mentioned above. The employees are the housewives of poor families in the city. They work for poor pay, which helps ont their meagre housekeeping. Nagata district, which is crowded with a lot of small chemical-shoes factories, 